\title{
11. New philanthropy and global policy networks in education: the case of Argentina
}

\section{Iván Matovich and Alejandra Cardini}

\section{INTRODUCTION}

This chapter describes how new philanthropy and global networks are starting to influence Argentina's education policy. Since a new administration took office in 2015, a significant political shift has welcomed new political actors in Argentina. In a traditional education policy context of non-pro-market conditions, these recent political changes have encouraged the incipient growth of new philanthropy. This chapter focuses on these new developments by analysing how the Varkey Foundation (VF), an internationally renowned example of new philanthropy, managed to 'land' in this country between 2016 and 2017.

More precisely, this chapter aims to explore how new philanthropy and global policy networks move people, ideas, money and logics within a particular context. This research tries to answer the following questions: To what extent could VF's activities within different 'microspaces' of the public arena be considered emerging experiences of new philanthropy? Are VF's activities a case of new philanthropy in Argentina (not as a totalising phenomenon, but as a rising type of power exercise)? Are these shifts evidencing a transition in the who and how of education policy in Argentina? Finally, in more theoretical terms, this work contributes to the study of new philanthropy developments in contexts with very limited promarket penetration. In other words, it is here asked to what extent this case might be considered a black swan or an emerging trend within Argentina's educational arena.

To answer these questions, a case study methodology was used. Studying the VF's landing in Argentina resulted in particular findings of a phenomenon (specific to time and space) that provided hints and references to address wider questions. The case study was approached with a network ethnography strategy (see, among others, Ball, 2012; Ball \& Junemann, 
2012; Dicken, Kelly, Olds \& Yeung, 2001; Edwards, 2008; Howard, 2002). In order to cope with the complexity of the problem, actors in these networks were identified. Their power, capacities and the ways through which they exercise their power through association within networks of relationships were analysed. This meant the use of extensive and exhaustive internet searches (webpages, documents, videos, social media, etc.) around particular organisations.

In addition, two in-depth interviews were conducted in May 2017 with Agustín Porres, Country Director (Argentina) and Fernando Gimenez Zapiola, Academic Director (Argentina). These interviews were conducted in Spanish and were translated by the authors. Questions addressed interviewees' profiles and work experience, their beginnings at VF, VF's landing process in Argentina, their main activities in this same country and long-term plans for the organisation. ${ }^{1}$

\section{NEW PHILANTHROPY: GOODNESS-DELIVERY AND NETWORKS DEVELOPMENT}

Among the many policy actors that have joined the education policy field in the last decades, this research focuses particularly on 'new philanthropists' (Ball \& Olmedo, 2011; Olmedo, 2014; Reckhow, 2012). Philanthropy can no longer be thought of as a funding transfer from the private to the public sector or as a charitable practice. As Ball (2012) claims, new philanthropy is the direct connection between 'giving' and 'outcomes' and the direct involvement of giving in philanthropic action and policy communities (Ball, 2012). He claims that new philanthropy 'is based on three aims: bringing non-profits to scale by committing large blocks of funding over long periods of time; emphasizing the importance of evaluation and performance management; and fostering "investor-investee" relationships on the basis of "consultative engagement" (Ball, 2012 in Saura, 2016, p. 5).

Enterprise discourses and technologies have penetrated different organisations such as non-governmental organisations (NGOs), charities, not-for-profit companies, foundations, community organisations, and public-private partnerships. These organisations are becoming more interrelated and influential in policy-making (Ball \& Junemann, 2012; Junemann \& Ball, 2013; Olmedo, 2014; Reckhow, 2012). In fact,

\footnotetext{
1 This research was conducted during 2017. This chapter is based on Who trains our school managers? A case study of global policy networks in Argentina, a master programme dissertation developed at the Institute of Education of University College London.
} 
the boundaries between philanthropy, business and the public sector are being moved and blurred, the public sector generally is being worked on and re-worked by new policy actors, from the inside out (endogenous change) and the outside in (exogenous change). This is happening in particular through the dissemination of the values and practices of enterprise and entrepreneurship and the transposition of the 'international discourse of managerialism' (Thrift, 2005, p. 33, in Ball \& Junemann, 2012, p. 48)

This new philanthropy focuses on policy 'problem-solving' by the influx of private actors' money and enterprise models, as an alternative to the 'failing' state. As Marinucci (2007) says, 'we are now officially in the era of "phylantrepreneurs" where the difference between a VC [venture capital] fund and a foundation, a hot start-up and social venture become totally blurry' (cited in Ball \& Olmedo, 2011, p. 83).

As enterprises, new philanthropists seek clear and measurable results; impact evaluation becomes a key tool to monitor the efficiency of 'investments' of time and money. They operate under beliefs 'imported' from their business activities and they try to translate their 'entrepreneurial philosophy' into their philanthropic activities. Ideas like 'do more with less', 'grand challenges', 'silver bullets' and 'quick and cheap solutions' stand as logics and values that shape the who, how and where of policy-making (Ball \& Olmedo, 2011).

The most relevant aspect of new philanthropy in terms of power relations is its effect on governance. Philanthropic practices imply new models of governance, as these actors circulate with their money, logics, values and models throughout global policy networks and the educational policy arena is reconfigured. New 'policy-spaces' are opened within blurred sector-boundaries, as 'new philanthropists operate in a "parapolitical sphere" within which they can develop their own policy agenda' (Ball \& Olmedo, 2011, p. 83).

To approach this phenomenon, research requires an analysis of these actors within policy networks. As Olmedo (2014) explains, philanthropic governance demands exploring 'structure and practices of a set of new philanthropic individuals and organizations' to analyse 'their discourses, connections, ideological influences and agendas for change' (p. 576). There is a need to explore their characteristics and functioning mechanisms.

Several works in the education field have used this methodology to analyse how global organisations expand their influence. Absolute Returns for Kids (ARK) has been addressed by Olmedo (2014) and Junemann and Ball (2013). Similarly, Junemann, Ball and Santori (2016) have examined global policy networks related to Bridge International Academies; Mundy (2010) did so for Teach for All, among many others.

Among these cases, the VF is another example of an emblematic case of new philanthropy across the globe. It is one of many organisations 
depending on the Varkey Group Ltd (registered in the British Virgin Islands), and it is one of two not-for-profit organisations within the conglomerate (the other is the Everonn India Foundation).

The Varkey Group Ltd is an interconnected web of organisations that provides a wide range of services, especially in the United Arab Emirates (UAE). GEMS MENASA Ltd. (registered in Cayman) is the most important organisation within the group and it is based in the UAE. By March 2017, according to Bloomberg's overview, GEMS MENASA Ltd. announced unaudited earnings results for the last six months ended 28 February 2017. For the period, the company's revenue was USD 539.1 million compared to USD 466.8 million a year before (Bloomberg, 2017). This conglomerate's organisation holds School Improvement Partner Ltd (GEMS Education Solutions), Bright Bus Transport (BBT), Premier School International (LLC) and other separately owned schools.

As Ridge, Kippels and Shami (2016) claim, this conglomerate's growth is highly related to Sunny Varkey and his family's sophisticated marketing approaches. This approach is based on maintaining credibility with key stakeholders by 'the development of a network of high-profile individuals and recognized organizations' (p. 268). Regarding people within this network, Bill Clinton (former U.S. President), Tony Blair (former U.K. Prime Minister), Bill Gates (Microsoft's Founder and Chairman) and Irina Bokova (UNESCO's General Director) stand out among many other trans-sectoral influential actors.

$\mathrm{VF}$ is registered as a charity organisation. It was founded and registered in the United Kingdom in 2011 (Ridge et al., 2016). It is 'a not-for-profit organisation established to improve the standards of education for underprivileged children throughout the world. [Their] mission is that every child should have a good teacher' (Varkey Foundation, June 2017d).

According to its website, the organisation addresses these aims by organising 'advocacy campaigns to promote excellence in teaching practice' and by 'building teacher capacity' (Varkey Foundation, 2017d). Within the Foundation's advocacy campaigns, it is possible to identify two 'star' events and main marketing drivers: the Global Teacher Prize and the Global Education and Skills Forum. ${ }^{2}$ The Foundation claims to have

2 These two events work as key advocacy tools. They gather high-profile policy-makers, former country leaders, experts and company CEOs, among many influential actors. The Global Teacher Prize has even been called by mass media the 'teaching Nobel Prize'. Please see 'Dos argentinos en camino al "Nobel" de la educación' ['Two Argentines on their way to the Educational "Nobel" prize'] (Vázquez, 2017); 'Los dos maestros argentinos quedaron afuera de la carrera por el "Nobel de la Educación"" ['The two Argentine teachers were left out of the race for the "Nobel of Education Prize"'] (Infobae, 2018); 'Teacher who won \$1m will use windfall to get artists into schools' (Brown, 2018). 
'launched the Global Teacher Prize to give incredible teachers from all over the world the recognition they deserve' (Varkey Foundation, 2017d). ${ }^{3}$ Continuing to cultivate capacity, the Foundation has developed several programmes in Ghana, Uganda and Argentina.

\section{ARGENTINA'S EDUCATION SYSTEM AND RECENT POLITICAL SHIFTS}

During the last decades, new philanthropy has grown in a context of global trends marked by policy network development, neoliberal reforms and a boundary-blurring between the public and private sectors. However, Argentina's education system has kept itself relatively isolated from this phenomenon when compared to other countries. Although this country suffered neoliberal reforms during the 1990s and enrolment rates in private schools have steadily grown during the last few decades, education has stood as a space of resistance to many neoliberal reforms and practices in all its levels. As many studies state, Argentina has gone through a process of privatisation without pro-market policies and reforms (Beech \& Barrenechea, 2011; Narodowski \& Moschetti, 2015).

However, in December 2015, Argentina suffered important political transformations. In very general terms, this change meant a shift from a centre-left government to a centre-right one. Cambiemos, the winning centre-right wing coalition, integrated by Pro and Unión Cívica Radical, not only kept its political power in Buenos Aires City, but it also reached the highest power executive positions that parties can hold in Argentina's political system: the national presidency and Buenos Aires province governorate. ${ }^{4}$ In addition, Cambiemos allied parties won elections in two other provinces, Jujuy and Mendoza, out of the 24 jurisdictions that make up Argentina's federal system. ${ }^{5}$

3 The foundation presents other advocacy activities such as the Global Education and Skills Forum, the Global Youth Survey, the Global Teacher Status Index and Business Backs Education.

4 Two aspects of this political power must be highlighted. First, the national presidency has historically been a very powerful position in Argentina, as well as in other Latin American countries. Second, Buenos Aires province governorate stands as a key political position. This jurisdiction holds 39 per cent of Argentina's population (Rivas, Coria \& Scasso, 2012) and it produces roughly 35 per cent of its gross domestic product (Di Santi, 2015). Such importance is also reflected in the educational field. This province has almost 40 per cent of Argentine students under its administration and the highest proportion of schools and teachers in the country.

5 Jujuy Province changed from Frente para la Victoria to Frente Cambia Jujuy (allied with Pro) and Mendoza Province changed from Frente para la Victoria to Alianza Cambia 
This victory obliged Pro to 'export' many of its political members from Buenos Aires city departments to national departments. The educational field was not an exception in this trend; the city's Minister of Education, Esteban Bullrich, was appointed as National Minister of Education, and many of his team members migrated from the city's government to the national sphere. In other words, Pro's political spectrum in the education field was significantly widened after December 2015, as it enlarged its capacity to reach more provincial education systems. Bullrich left this position in December 2017 to be a National Senator, but as will be described in further sections, he had a key role in VF's landing in Argentina.

This political transformation introduced 'tailwind' conditions and opportunities for new philanthropy trends in Argentina's education policy. In this context, VF signed a contract in 2016 with the National Ministry of Education (NMOE) and began implementing different programmes. VF has managed to grow in a scenario with a strong public tradition, active teacher unions and non-pro-market conditions.

According to one of its members, Argentina has become today the organisation's largest quarter worldwide in terms of staff members. VF is an emblematic educational philanthropic organisation operating across the globe and a very interesting case study to examine new philanthropy and global policy networks in a new context.

\section{HOW DID THE VARKEY FOUNDATION 'LAND' IN ARGENTINA? KEY EVENTS, NODAL ACTORS AND PRIVATE PARTNERS}

VF's most important programme in Argentina was first introduced in 2016 through an agreement with the NMOE. It is a six-week intensive training initiative called Programa de Liderazgo e Innovación Educativa (PLIE) [Leadership and Innovation in Education Programme]. It started in Jujuy and Mendoza provinces, it expanded to Salta and Corrientes during 2017 and it has recently begun in Buenos Aires. ${ }^{6}$ At the present, 4,700 school principals have already been trained throughout five Argentine provinces.

\footnotetext{
Mendoza (allied with Pro). These were the only two provinces, apart from Buenos Aires Province, that experienced significant changes in terms of governing parties; as mentioned before, Buenos Aires City had been already governed by Pro. The remaining 20 jurisdictions re-elected ruling parties (Del Cogliano \& Varetto, 2016). In further sections, these two provinces will be shown to have significant importance for this research.

6 As mentioned in the introduction, this is Argentina's largest province in most key dimensions: population, number of schools, students and teachers.
} 
Regarding funding, VF's Country Director in Argentina, Agustín Porres, confirms that the programme's main activities are fully financed by the NMOE: 'It is like a service that the National Ministry offers to provinces and then, the foundation does contribute a lot, let's say, by bringing specialists from London every week' (personal communication, 2017). Principals and teachers are authorised by provincial Ministries to attend this full-time programme for six weeks, while their positions are covered by vice-principals or substitute teachers hired by the Ministry of Education of each province.

The NMOE hired VF to provide training services to provinces. Indirectly, provinces bear the cost of having teachers and principals out of schools over the six weeks. Such a funding combination seems to be one of the clearest pieces of evidence of boundary-blurring among sectors; in addition, it raises questions about a possible case of what Ball and Olmedo (2011) call 'philanthrocapitalism'; that is, 'a merging of venture philanthropy with social enterprise as a new "economic rationalization of giving" (Saltman, 2010, p. 70)' (p. 84).

Such boundary-blurring is also observed in the professional background of VF's leadership team. When VF began its work in Argentina in 2016, the organisation's leading team was governed by Chief Executive Vikas Pota. Between 2010 and 2015 he had worked as Group Director of Corporate Affairs at GEMS Education (Pota, n.d.; Varkey Foundation, 2017c); thus, he came from the 'enterprise-side' of the conglomerate. In 2018, Cate Noble replaced Pota. Similarly, Noble has expertise in institutional strategy and design (from early years to higher education), programme design and implementation and education partnerships, and was previously a Director at PricewaterhouseCoopers $(\mathrm{PwC})$ and prior to that Head of Development at Education Development Trust (Varkey Foundation, 2018).

Considering Argentina's characteristics, VF managed to 'land' this programme in a context that a priori seemed reluctant to new philanthropy development. As explained in the following sections, this landing was based on nodal actors, key events and the participation of private partners.

\section{NODAL ACTORS AS BOUNDARY-SPANNERS AND 'NEW-LOGICS ENABLERS'}

A nodal actor is a 'boundary-spanner', a 'key agent managing within inter-organizational theatres' (Williams, 2002 in Ball \& Junemann, 2012, p. 87). A nodal actor is able to play a central role within a particular cluster, especially supported by 'a background that includes work across a range 
of fields and sectors operating in business, philanthropy and quasi-public sector roles in a highly networked career' (Williams, 2002 in Ball \& Junemann, 2012, p. 89).

These actors have a key role within policy networks because they move throughout it as solution-carriers who circulate ideas especially related to enterprise logics ('entrepreneurship', 'innovation' and 'creativity'). They blur the limits between fields and sectors and converge language and practices; for example, they operate as translators of business into philanthropy and they legitimise philanthropic ideas and values within policy (Ball \& Junemann, 2012). These actors could be also called 'new experts' within networks, as they 'act as vital intermediaries, mobilizing epistemic communities, but they also develop knowledge and data to inform decision-makers' (Shiroma, 2014, p. 337). Furthermore, literature suggests that these actors act as 'policy network animators' as it is possible to see how their social relations, the 'people they know', have effects on policy circulation and implementation (Ball, 2012; Ball \& Junemann, 2012; Olmedo, 2014; Rizvi \& Lingard, 2010; Saura, 2016). This is the case of the nodal actors analysed in the following paragraphs.

When looking at the landing of VF in Argentina, the role of nodal actors is fundamental. The most important position of the Foundation's team is Country Director and it has been occupied since 2016 by Agustín Porres (Varkey Foundation, 2017c). Before working for VF, Porres worked as Institutional Relations Coordinator for two and a half years at the Education Department in Buenos Aires City (2010-2012) while Esteban Bullrich was Minister of Education of this same state, among other positions. In addition, during his graduate studies, in 2015, Porres started working as Chief Executive at FormarHub Foundation, a non-profit organisation "with ties to both Latin America and the United States that connects education innovators and offers a platform for the development of new ideas, supports innovative approaches to education, and promotes successful practices' (FormarHub, 2017).

When analysing Porres's appointment as Country Director, evidence shows three determinant factors: his education profile, his management experience and his personal network. The two latter factors are related to his professional experience, not only in the education sector, but in management positions in both the 'third' (NGOs, civil society organisations, etc.) and public sectors. The attractiveness of Porres's profile for the Foundation seems to be especially related to the possibility of having direct contact with the NMOE and his management experience. Porres is a 'nodal actor' within the global and local policy networks in which VF moves.

VF's landing in Argentina cannot be understood without analysing another nodal actor: Esteban Bullrich. His active interest and participa- 
tion in VF's activities while he was Education Minister of Buenos Aires City and his later active role as National Education Minister was a very important part of the landing process. The following paragraphs depict such nodal conditions by describing key events and background 'moves' through VF's network in order to understand how 'landing-capacity' was developed.

By July 2016, Bullrich, National Minister of Education, visited the Governor of Jujuy Province, Gerardo Morales and its Minister of Education, Isolda Calsina. He was accompanied by the president of VF, Vikas Pota, and the Executive Director of Lego Education, Brian Baptista. This visit was related to the inauguration of the country's first Infinito por Descubrir (Infinite to be Discovered), ${ }^{7}$ a technological innovation centre produced by a public-private partnership. During this visit, Bullrich said that they were working on giving modern tools to teachers working in provinces and that they had been doing this at the national level. He said that they were doing it with some organisations like Harvard's School of Education, with the Lego company, and with the Varkey Foundation, who were going to help them (Jujuy's government) to lead a change in Jujuy regarding innovation in the use of technologies to improve children's learning and to improve education quality (Varkey Foundation, 2017a). ${ }^{8}$ Three months later, on 31 October 2016, Calsina and Desmond Bermingham, former Head of Programmes of VF, led the inauguration of VF's main programme in this province (Gobierno de Jujuy, 2016): Programa de Liderazgo Educativo (Education Leadership Programme). Similar events took place in Mendoza in February 2017 (Mendoza Gobierno, 2017) and in Corrientes and Salta in May 2017 (El Litoral, 2017; Varkey Foundation, 2017b).

As evidence shows, VF's landing in Argentina is highly related to Esteban Bullrich, his network and recent political alliances. In order to understand this key influence, it is necessary to retrieve former events and link them with evidence provided by the case study and interviews.

In March 2015, Bullrich attended the Global Education and Skills Forum (GESF) organised by VF. He participated in the Plenary called 'The

7 Infinite to be Discovered is a NMOE and Sports initiative through Educar SE, and it relies on the effort of the provincial and local governments, social organisations, private companies and communities in which centres are located. It is a non-formal educational programme that aims to stimulate and encourage children and youth's soft abilities and vocations from six to 18-years old by creating projects based on disciplines like robotics, programming, video gaming, art, design and biotechnology (Infinito por Educar, 2017). The programme seems to be highly related to Olivia Consultoría de Change Management (a consulting company), as it is directed by Gabriel Weinstein, associate consultant of this company.

8 Authors' translation. 
Teacher and Society' where he said: 'We are comfortable with not challenging the education system... . We need to change the school system. We are asking teachers to take kids to the moon, but we are only upgrading a car instead of building a rocket' (Global Education and Skills Forum, 2015).

After the panel, Bullrich was interviewed by GESF organisers, and he expressed his desire to have Argentinian teachers participating in the next Global Teacher Prize awards. Nine months later, on 14 December 2015, four days after taking over the NMOE due to Pro/Cambiemos party's electoral victory, President Macri received Argentine candidates for the Global Teacher Prize.

These events support Porres's reference about the role played by Bullrich in the Foundation's activity in Argentina and his particular interest in VF. When Porres was asked about Bullrich's relationship with the Foundation, he said:

He once came to a Dubai conference [Global Education and Skills Forum 2015] ... In one of the forums he liked it and he said that if someday he was a National Minister he would like the Varkey Foundation to work in Argentina. And he came last year and he said 'Well, now I'm the Minister'. (personal communication, 2017)

Furthermore, when Porres was asked how VF managed to start working in Argentina and what the key factors were, he said:

I think that Esteban Bullrich was really decided to do it... . He called us and we had a meeting where he told us he had a plan and said 'we need a plan in August 2016'. We answered: 'Fine, we will do it for March 2017, so we can contextualise content'. And he said: 'No, March 2017? There are a thousand years to March 2017. We need it right now'. (personal communication, 2017)

Such pieces of evidence contribute to identifying Bullrich as the main enabling node within the network where VF moves within Argentina. Past events and Porres's words show that the ex-Minister had a special interest in the Foundation's activities even before he took his position as National Minister.

However, and more importantly, these actors share an epistemic regarding forms of addressing and defining education policy problems that will be described in the following paragraphs. They represent new voices within the policy arena. This is related to Ball and Junemann's (2012) definition of policy communities: 'a set of specific network relations and on a highly interlinked "policy community" that "catalyses" philanthropy and business in the delivery of education services and reconfigures and disseminates a particular set of education policy discourses' (p.9). 
Bullrich is a nodal actor within this policy community. His enabling role emerges as a key fact when the political context is considered. Jujuy and Mendoza had been the only two provinces clearly aligned with the Pro/ Cambiemos party since elections in 2015. However, interviewees do not recognise or mention this important political fact when they are asked why Mendoza and Jujuy provinces were initially selected to implement the programme. Although Bullrich has great influence to 'land' the programme due to Mendoza and Jujuy's political commitment to the national government, Porres explains such a landing process based on the ideas of necessity, opportunity, possibility and willingness:

In its basis, this is a programme that the National Ministry brings to support provinces.. . . It is a conjunction of necessity, opportunity and possibility. This means that there is a province that is able to receive this programme, that wants to receive it and that needs it. And it is not easy to receive this type of programme. Province Ministries are shaken up... . This programme adds a lot of value, but you have to be willing to work a lot. (personal communication, 2017)

This shows the absence of traditional arguments - such as political agreement and ideology to explain why the programme is implemented in certain specific provinces. While decision making and implementation in public policy could be explained by political agreements, ideological perspectives or unions' resistance, Porres relates this situation to a willingness and a business perspective focusing on necessity, opportunity and possibility. There has been evidence in other contexts of the significance of political willingness in terms of particular policy-makers willing to engage and carry out reform (Barber, 2013); this conception tends to be strongly related to an enterprise discourse.

Porres's argument shows how the intervention of private actors within education policy might not only blur the limits between the public and the private sector, but it could also contribute to de-politicising certain arenas that are necessarily crossed by power relations. Instead of evaluating policy possibilities (or impossibilities) in terms of ideological and political agreement (or conflict), arguments are built on a 'willingness to do'.

This approach is also seen in the Academic Director Fernando Gimenez Zapiola's perspective about the advantages of being a 'third party' between teachers and the state:

It is very useful to be a foundation or a third-party actor when delivering the training. There is no space for catharsis, neither for recrimination for those things that the state is not providing... . When you are the state, you are recriminated. Things like 'Hey, this is fine, but I don't have desks at the school' are not said... . Since we are a third-party, teachers adopt a lot what it is happening because they separate their employer (and the one who should provide services) 
from who's working with them at a specific moment. (personal communication, 2017)

These words provide more examples to assist in understanding the Foundation members' perspectives about their roles from a policy point of view. VF takes many of the responsibilities usually attributed to the state, such as teachers' and school managers' training. In addition, it is hired and supported by the state and it works on the structure: schools, departments, recruitment services, and so on. Nonetheless, it is not the state, but a foundation that claims to change lives through education and that wants every child to have the best teacher. In this sense, the Foundation and the state are 'shielded' from political conflicts. At the same time the latter is able to reach its workers, eluding political confrontation or conflict. As in the case of the programme's funding, this description depicts the hybrid conditions in which the state and private actors operate. ${ }^{9}$

\section{PRIVATE ACTORS JOINING THE NETWORK: LEGITIMATORS AND CATALYSERS}

The VF's activities in Argentina are also related to relationships with other private partners that seem to move through similar circuits within the network. All these share activities and perspectives, while they shape an epistemic community.

The following paragraphs provide pieces of evidence of the relation between the public sector, VF and private partners. These demonstrate the circulation of what Ball (2007) calls 'improvement products'. These are 'solutions' 'which are marketed to educational institutions by education services companies [or other types of organisations like foundations, charities, not-for-profit organisations, etc.] and their role in re-working and surveilling those institutions' (Ball, 2007, p. 135).

As evidence shows, these solutions are not linearly replicated when they are mobilised. McCann (2013) explains such a dynamic as a non-replicating policy mobilisation; this means that policies are not transferred by policy

9 Such dynamics within policy networks seem to reconfigure who influences policy delivery and decision making. The studied case could be considered as extra evidence of what Ball (2012) describes as 'the beginning of the end of state education and its "welfare' form(s)"" (p. 2). More precisely, it is possible to claim that this new type of governance within policy networks raises questions about democratic deficit and opacity; after all, 'these people, their relationships and interactions and morality and money and ideas and influence are transforming social, economic and political relations and enacting the neo-liberal imaginary in very real and practical ways in education and education policy' (Ball, 2012, p. 145). 
boosters as 'prepackaged solutions', 'but through a complex sociospatial process of emulation and transmutation that has uneven consequences for cities and citizens that cannot necessarily or easily be separated from the contexts from which they were spawned' (p.20). It is a form of practice that stands on continuous processes of assemblages, interest considerations and necessary adaptations to local power relations.

Findings show that private partners played a key role for 'landing', as they managed to introduce and boost particular policies, ideas and discourses within a given context. In the following paragraphs, we analyse the particular participation of Edúcere and Michael Lightfoot Associates (MLA), two key private partners, among others, that contributed to VF's landing in Argentina. We first examine Edúcere's local perspective and we then examine MLA's global approach.

From a local point of view, the participation of Edúcere, a not-for-profit civil association, in the VF programme's launch and adaptation, especially in its first steps during the pilot process, was very important. According to its website, Edúcere was registered in Tandil City (Buenos Aires province) and has delivered training programmes and advice to teachers and school directives since 1998 (Edúcere, 2017). Founded and directed by Victoria Zorraquin, this organisation aims to offer enriching and renovating approaches for teacher training and advice (Edúcere, 2017).

The VF Academic Director, Gimenez Zapiola, remarks on the importance of Edúcere by describing it as an external actor that 'helps' and 'catalyses' the programme, but at the same time, it could be argued that it has worked 'from inside' in many of the programme's dimensions. When he was asked about the training programme's pedagogical content, he explained that the training syllabus was translated, adapted and contextualised in a work-process in which Edúcere actively participated: 'Originally, the training syllabus was a ten-week programme. It was shortened to six weeks. All this material was translated with a public official translator. Edúcere participated in this process' (personal communication, 2017). He also explained that Edúcere was highly involved in the first six-week pilot that took place in Jujuy: it adapted the contents and produced a results report of the pilot initiative. At the same time, all teacher trainers were members of this organisation in that first programme launch, except for one local member:

From all those six weeks Edúcere produced a report of the programme pilot, an external coordinator called Carlos Concha also made one, and Michael [Lightfoot] made another.. .. They [Edúcere] made this first contextualization and the pilot was mostly delivered by Edúcere, with a local member from Jujuy.. . . Actually, this content and everything belongs to Varkey, though we all have made contributions. ... Let's say, it belongs to the Foundation and we keep 
enriching it from our [Argentine VF members'] own experiences. (F. Gimenez Zapiola, personal communication, 2017)

As evidence suggests, Edúcere supported VF to develop the programme in its beginnings. This is not a minor detail; as mentioned in a previous statement, the programme's capacity to develop a 'quick-launch' has had a key role in the programme's setting. In other words, Edúcere could be classified in the group of those companies that 'present themselves in terms of commitments to the public good and to bringing the public sector into "the new" - saving it from itself and solving its problems' (Ball, 2012, p. 137).

Edúcere was not the only key private partner that VF recruited for its landing process. If Edúcere worked as a local partner, it could be argued that MLA was a key foreign private partner for this same process.

MLA is an international consultant for education and personal development - recent contracts in Argentina, Azerbaijan, Barbados, Afghanistan. School leadership development, incorporating yoga practice, personal reflection and team building' (Lightfoot, n.d.). The company has been led by Michael Lightfoot as Principal Consultant since June 2014. Lightfoot has vast experience with international consulting in the education field and working with the private sector.

MLA had an important role in VF's work in Argentina. According to Gimenez Zapiola: When the programme was starting, I contacted one of the education consultants who came to work in Argentina for the programme's deployment. $\mathrm{He}$ is called Michael Lightfoot. He is the one that created this original training programme and he is the one who worked in adapting the training programme from the original version to the one that we are finally using. He came to Jujuy's capital city and I was with him three whole days working all day long. Once we finished, I wrote a report to him with the first results of the implementation. (personal communication, 2017)

These words are highly significant in terms of policy mobilities and 'global assemblages' (Ong, 2006 in Ball, 2012). The interviewee remarks on the influence that this international consultant has had for the foundation's landing and development in Argentina; not only did he create the original programme for another assignment, but he also worked on its adaptation to specific contexts and he monitors this process. This form of practice could be related to what McCann (2013) calls 'policy boosterism'; that is, 'a subset of traditional branding and marketing activities that involves the active promotion of locally developed and/or locally successful policies, programs, or practices across wider geographical fields as well as to broader communities of interested peers' (p. 5). In this trend, Lightfoot could be described as a 'policy booster', an actor that has an important role in mobilising education policies throughout global policy networks. 
Moreover, the Foundation members describe the 'adaptation' component as an important and necessary task. Although the programme had already been designed, the Foundation has focused on the programme's adaptation and a constant movement 'between London and Argentina'. Porres, Country Director, says, 'Truth is that everything has been designed in London.... We then worked with a team of fifteen specialists to "Argentinize" it' (personal communication, 2017). In addition, Gimenez Zapiola, Academic Director, claims:

I gathered result reports of the first pilot experiences from all participants [Edúcere, Michael Lightfoot Associates, External Consultant Carlos Concha]. All that material, plus the one that came from London was here. ... My job was to re-signify all that to learn from that experience. (personal communication, 2017)

These words exemplify how policies flow through networks at the same time that they are adapted to them. Such movements and adaptations involve different actors coming from diverse areas and with different interests and influences, assembling a discourse that is permanently legitimated by the network itself.

This landing process and private partners' participation are clearly interrelated. Such a form of policy-delivery is a key aspect to understand VF's case because, as mentioned before, Argentina is a context where this type of practice rarely takes place. Thus, if considered a relative exception, we found it interesting to ask how the organisation managed to 'squeeze' into the system.

\section{CONCLUSIONS}

By describing the Varkey Foundation's 'landing' process in Argentina, this chapter analysed new power relations within Argentina's education policy, considering new philanthropy and global policy networks. It looked at specific and concrete aspects of this expansion: the role of nodal actors and private partners' networks.

In regard to nodal actors' influence within new philanthropy activities, the VF case in Argentina is a clear example of policy-boosterism (McCann, 2013) among certain actors as a practice that allows introducing new forms of doing policy. Findings evidence the importance of nodal actors-Bullrich and Porres - to 'land' VF's programme in Argentina. Our findings show how they managed to effectively move between local and global contexts and to introduce new philanthropy discourses associated with entrepreneurship, innovation, speed and efficiency. Furthermore, they 
clearly enacted a boundary-blurring between the public and the private sectors; they moved, acted and implemented their practices in these 'grey' overlapped perimeters.

Moreover, this chapter showed how private partners acted as catalysts when new philanthropy was directly linked with policy mobilities. VF counted on local and foreign support of private partners such as Edúcere (local) and MLA (foreign) in order to accomplish a quick programmelaunch. These institutions had an important role in adapting the training syllabus to local contexts, to 'Argentinize' the programme, as well as in the delivery during the pilot stages.

The relevance of this chapter is related to VF's penetration into an arena where new philanthropy rarely has a place. While new philanthropy and policy mobilities are usually associated with high levels of privatisation and pro-market contexts, Argentina's public education has remained very strong and the penetration of pro-market policies is low when compared with other countries. This first exploratory research allows reflection on such a theoretical framework. While some authors argue that Argentina is an example of growing privatisation without pro-market policies, this research contributes to arguing that new philanthropy might not require such conditions for its development; pro-market and privatisation could be a 'catalysing' element, but not a fundamental condition for the expansion of new philanthropy.

Hence, it is necessary to ask to what extent VF's case is a black swan or an emerging trend in Argentina's context. On one hand, VF's recent expansion and its private partners' growing activity show that new philanthropy is an emerging phenomenon. On the other hand, this case is a black swan, as it is an atypical answer to those premises that 'naturally' relate new philanthropy development with pro-market contexts.

Furthermore, this might work as an input to further work in this field. Such a 'black-swan condition' might be reinforced by the idea that VF's 'landing' in Argentina is strongly related to hierarchical and centric government of the education system. This is a counterargument for those premises that claim that new philanthropy needs heterarchical governance and state polycentrism. This is evidenced in the central role that governments (national and provincial) have had in the programme's 'landing' in public education. Decisions taken by the National Minister have had a key role in funding the implementation of VF's training programme; at the same time, provinces with clear political alliances are those who opened 'landing' possibilities.

Last but not least, these findings may raise new questions on the conceptual and practical implications of new philanthropy for democracy, influences and policy-making. As Ball and Olmedo (2011) say, new 
philanthropists 'are able to modify meanings, mobilise assets, generate new policy technologies and exert pressure on, or even decide, the direction of policy in specific contexts' (p.87). Thus, it is necessary to reflect on the interests and drivers that are operating when a private foreign organisation makes and delivers policy in Argentina with public resources.

\section{REFERENCES}

Ball, S. J. (2007). Education plc: Understanding private sector participation in public sector education. Oxon, UK: Routledge.

Ball, S. J. (2012). Global Education Inc. Oxon, UK: Routledge.

Ball, S. J., \& Junemann, C. (2012). Networks, new governance and education. Bristol, UK: The Policy Press, University of Bristol.

Ball, S. J., \& Olmedo, A. (2011). Global social capitalism: Using enterprise to solve the problems of the world. Citizenship, Social and Economics Education, 10(2), 83-90.

Barber, M. (2013). The good news from Pakistan: How a revolutionary new approach to education reform in Punjab shows the way forward for Pakistan and development aid everywhere. London, UK: Reform.

Beech, J., \& Barrenechea, I. (2011). Pro-market educational governance: Is Argentina a black swan? Critical Studies in Education, 2(3), 279-293.

Bloomberg. (2017, March 23). GEMS MENASA (Cayman), Ltd. announces unaudited earnings results for six months ended February 28, 2017. Retrieved March 23, 2017, from https://www.bloomberg.com/research/stocks/private/snapshot. asp?privcapId $=71987219$

Brown, M. (2018, June 26). Teacher who won $\$ 1 \mathrm{~m}$ will use windfall to get artists into schools. The Guardian. Retrieved June 28, 2018, from https://www.theguardian. com/education/2018/jun/26/1m-teaching-prize-winner-launches-uk-school-arts-ch arity

Del Cogliano, N., \& Varetto, C. (2016). Las elecciones subnacionales de 2015 en Argentina: estabilidad con cambio [The subnational elections of 2015 in Argentina: stability with change]. Revista Uruguaya de Ciencia Politica, 25(1), $13-37$.

Di Santi, M. (2015, December 14). Vidal: 'La Provincia aporta el 35\% del PBI, y recibe menos del $18 \%$ de los recursos coparticipables' [Vidal: The Province contributes $35 \%$ of the GDP, and receives less than $18 \%$ of the co-participable resources]. Chequeado. Retrieved December 14, 2016, from: http://chequeado. com/ultimas-noticias/vidal-la-provincia-aporta-el-35-del-pbi-y-recibe-menos-del18-de-los-recursos-coparticipables/

Dicken, P., Kelly, P. F., Olds, K., \& Yeung, H. W-C. (2001). Chains and networks, territories and scales: Towards a relational framework for analysing the global economy. Global Networks, 1(2), 89-112.

Edúcere. (2017). Qué es Edúcere? [What is Edúcere?]. Retrieved June 27, 2017, from http://www.educere.org.ar/nosotros.html

Edwards, M. (2008). 'Philanthrocapitalism' and its limits. International Journal of Not-for-Profit Law, 10(2), 22-29.

El Litoral. (2017, April 3). Educación implementará un programa de liderazgo e 
innovación curricular para directores [The Ministry of Education will implement a leadership and curricular innovation programme for school principals]. Retrieved June 20, 2017, from https://www.ellitoral.com.ar/457187/Educacionimplementara-un-programa-de-liderazgo-e-innovacion-curricular-para-directores

FormarHub. (2017). About us. Retrieved June 24, 2017, from http://www.formarhub. com/formarhub/

Global Education and Skills Forum. (2015). GESF 2015 plenary: The teacher in society. [Video file]. Retrieved June 24, 2017, from https://www.youtube.com/wat ch?v=I98nq7_eHVI\&t=2259s

Gobierno de Jujuy. (2016, October 31). Comenzó el programa de Liderazgo Educativo [The educational leadership has begun]. Retrieved December 10, 2016, from http://educacion.jujuy.gob.ar/2016/10/31/comenzo-el-programa-de-liderazgo-edu cativo/

Howard, P. N. (2002). Network ethnography and the hypermedia organization: New media, new organizations, new methods. New Media Society, 4(4), 550-574.

Infinito por Educar (2017). ¿Qué es IxD? [What is IxD?]. Retrieved May 2017, from http://educacion.gob.ar/infinito-por-descubrir/seccion/156/que-es-ixd

Infobae. (2018, February 13). Los dos maestros argentinos quedaron afuera de la carrera por el 'Nobel de la Educación' [The two Argentine teachers were left out of the race for the 'Nobel of Education Prize']. Retrieved March 2, 2018, from https://www.infobae.com/educacion/2018/02/13/los-dos-maestros-argentinos-que daron-afuera-de-la-carrera-por-el-nobel-de-la-educacion/

Junemann, C., \& Ball, S. J. (2013). ARK and the revolution of state education in England. Education Inquiry, 4(3), 423-441.

Junemann, C., Ball, S. J., \& Santori, D. (2016). Joined-up policy. In K. Mundy, A. Green, B. Lingard, \& A. Verger (Eds.), The handbook of global education policy (pp. 535-553). Chichester, UK: Wiley-Blackwell.

Lightfoot. (n.d.). Dr. Michael Lightfoot. Principal at Michael Lightfoot Associates. Retrieved June 30, 2017, from https://www.linkedin.com/in/dr-michael-lightfoot $-4575061 /$ ?trk=public-profile-join-page

McCann, E. (2013). Policy boosterism, policy mobilities, and the extrospective city. Urban Geography, 34(1), 5-29.

Mendoza Gobierno. (2017, February 24). La DGE capacita a directores en innovación y liderazgo [The General Directorate of Schools trains principles on innovation and leadership]. Retrieved February 24, 2017, from http://prensa.mendoza. gov.ar/la-dge-capacita-a-directores-en-innovacion-y-liderazgo/

Mundy, K. (2010). 'Education for All' and the global governors. In M. Finnemore, D. Avant, \& S. Sell (Eds.), Who governs the globe? (pp. 333-355). Cambridge, UK: Cambridge University Press.

Narodowski, M., \& Moschetti, M. (2015). The growth of private education in Argentina: Evidence and explanations. Compare: A Journal of Comparative and International Educational, 45(1), 47-69.

Olmedo, A. (2014). From England with love. . ARK, heterarchies and global 'philanthropic governance'. Journal of Education Policy, 29(5), 575-597.

Pota. (n.d.). Vikas Pota. Chief Executive at Varkey Foundation. Retrieved June 24, 2017, from https://www.linkedin.com/in/vikaspota/

Reckhow, S. (2012). Follow the money: How foundation dollars change public school politics. Oxford, UK: Oxford University Press.

Ridge, N., Kippels, S., \& Shami, S. (2016). Economy, business and first class. In 
A. Verger, C. Lubienski, \& G. Steiner-Khamsi (Eds.), World yearbook of education 2016. The global education industry (pp. 264-288). Oxon, UK: Routledge.

Rivas, A., Coria, J., \& Scasso, M. (2012). Balance de la gestión educativa de la provincial de Buenos Aires (2007-2011) (Documento de trabajo Nro. 89) [Balance of the educational management of the province of Buenos Aires (2007-2011)]. Buenos Aires, Argentina: CIPPEC, Programa de Educación, Área de Desarrollo Social.

Rizvi, F., \& Lingard, B. (2010). Globalizing education policy. Oxon, UK: Routledge.

Saura, G. (2016). Saving the world through neoliberalism: Philanthropic policy networks in the context of Spanish education. Critical Studies in Education, 59(3), 1-18.

Shiroma, E. O. (2014). Networks in action: New actors and practices in education policy in Brazil. Journal of Education Policy, 29(3), 323-348.

Varkey Foundation. (2017a). Bullrich: 'Queremos darle a los docentes herramientas de modernidad' [Bullrich: 'We want to provide teachers with modern tools']. Retrieved May 5, 2017, from http://www.fundacionvarkey.org/2016/07/27/bul lrich-queremos-darle-a-los-docentes-herramientas-de-modernidad/

Varkey Foundation. (2017b). Jornada sobre liderazgo e innovación en Corrientes [Conference on leadership and innovation in Corrientes]. Retrieved May 5, 2017, from http://www.fundacionvarkey.org/2017/05/09/planifican-capacitaciones-enliderazgo-e-innovacion-educativa-para-mas-de-3-000-directivos-y-docentes/

Varkey Foundation. (2017c). Our team. Retrieved June 24, 2017, from https:// varkeyfoundation.org/about/people-biogs

Varkey Foundation. (2017d). What we do. Retrieved June 23, 2017, from https:// www.varkeyfoundation.org/mission/what-we-do

Varkey Foundation. (2018). Our team. Retrieved November 6, 2018, from https:// www.varkeyfoundation.org/who-we-are/our-team

Vázquez, L. (2017, December 12). Dos argentinos en camino al 'Nobel' de la educación [Two Argentines on their way to the Educational 'Nobel' prize]. La Nación. Retrieved March 2, 2018, from https://www.lanacion.com.ar/2090836-dos-argen tinos-en-camino-al-nobel-de-la-educacio 